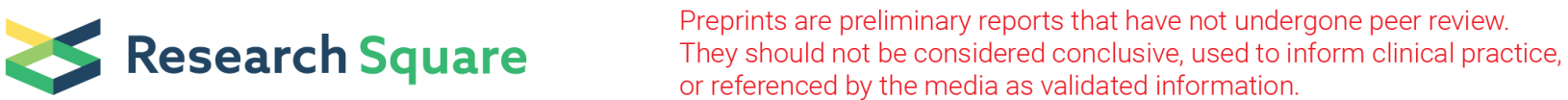 \\ Moss Establishment Success Is Determined By The Interaction Between Propagule Size And Species Identity
}

Fernando Hurtado ( $\nabla$ ferhurboc@gmail.com )

Museo Nacional de Ciencias Naturales (MNCN-CSIC)

\section{Belén Estébanez}

Universidad Autónoma de Madrid

Pedro Aragón

Museo Nacional de Ciencias Naturales (MNCN-CSIC)

Joaquín Hortal

Museo Nacional de Ciencias Naturales (MNCN-CSIC)

Manuel Molina-Bustamante

Universidad Autónoma de Madrid

Nagore G. Medina

Universidad Autónoma de Madrid

\section{Research Article}

Keywords: Asexual reproduction, bryophytes, colonization, dispersal, fitness, propagule establishment, traits.

Posted Date: March 7th, 2022

DOI: https://doi.org/10.21203/rs.3.rs-1358759/v1

License: (c) (1) This work is licensed under a Creative Commons Attribution 4.0 International License. Read Full License 


\section{Abstract}

Question: Colonization of new habitat patches is a key aspect of metacommunity dynamics, particulary for sessile organisms. Mosses can establish in new patches through fragmentation, with different vegetative structures acting as propagules. Despite the importance of these propagules for successful colonization the specific aspects that favour moss colonization by vegetative propagules remain poorly understood, including the effect of propagule size. We examine the intra- and interspecific variation of establishment and colonization success in culture of propagules of different sizes in six widespread, soil moss species of contrasting growth form (Dicranum scoparium, Homalothecium aureum, Hypnum cupressiforme, Ptychostomum capillare, Syntrichia ruralis and Tortella squarrosa).

Methods: We obtained three different size classes of propagules from artificially fragmented vegetative material, and assessed their establishment under controlled light and temperature conditions. We characterize the size, shape, apparent viability, morphological type and size changes due to hydration states of the propagules, all of them traits with potentially significant influence in their dispersal pattern and establishment. Then we assess the effect of these traits on moss establishment, using indicators of surface establishment (number of established shoots and colonized surface) and biomass production (viable biomass) as proxies of colonization success.

Results: The establishment indicators related to colonization surface and biomass production differ among species and propagule sizes. The magnitude of the interspecific differences of all indicators of establishment success was larger at the smaller propagule size class. T. squarrosa was the most successful species, and $D$. scoparium showed the lowest performance. We also found interspecific differences in the hydration dynamics of the propagules.

Conclusions: The process of establishment by vegetative fragments operates differently among moss species. Besides, differences between hydration states in propagules of some species could be part of syndromes for both dispersal and establishment. This study unveils several functional traits, such as wet versus dry area and length of fragments, relevant for moss colonization that may improve our understanding of their spatial dynamics.

\section{Introduction}

Understanding colonization dynamics is key for evolutionary biology and applied ecology as it modulates range shifts, between-populations connectivity and genetic fluxes ${ }^{1,2}$ Colonization is part of a multi-step invasion process that includes the generation of dispersible reproductive structures (propagules) in the source population, the dispersal of the propagules and their establishment ${ }^{3,4}$. Propagule production and dispersal are the first steps of the colonization process and imply a sufficient production of viable diaspores and its transport to a new locality ${ }^{5}$. However, the establishment often the most limiting step for colonization $^{6-8}$ (but see ref. 4), and thus determines metacommunity dynamics and changes in the limits of species distributions. It serves as the anchor of new dispersal events and the starting point of 
perdurable changes in both ecosystem and evolutionary dynamics. Indeed, establishing viable populations in new suitable habitat patches is determinant for the species continuity under current global change scenarios (e.g. ref. 9). Due to this, there has been an increase in the number of studies that integrate migration potential into distribution modelling ${ }^{10}$. Nevertheless, for these approaches to be useful we need realistic data that account for an accurate estimation of the colonization potential. However, most studies analysing the effects of colonization processes on the ability of populations to track suitable environments focus mainly on the dispersal ability of the species, neglecting the role of their establishment potential and its links with diaspore traits.

Mosses are a good model for assessing establishment success experimentally. Like the rest of land plants, they are sessile organisms in which the establishment success depends directly on the ability to grow in situ. However, they have unique characteristics that make them interesting for the study of colonization processes. Although they reproduce by sexual spores (meiospores) or specialized vegetative propagules such as gemmae or bulbils, as in Bryum s.l., including Ptychostomum ${ }^{11,12}$, mosses are predominantly clonal organisms that routinely reproduce from undifferentiated vegetative tissues ${ }^{11,13-15}$. Simple fragments of adult shoots, rhizoids and also detached leaves can serve as propagules, as in Tortella squarrosa ${ }^{16}$. This is so because in mosses even single cells have the potential to generate new plants (totipotency sensu ref. 17). Fragmentation, as a vegetative reproduction mode, greatly increases the potential for local expansion of populations in the absence of ${ }^{18}$, or complementary to, sexual reproduction, and entails unique population dynamics among bryophytes ${ }^{11,19-21}$.

The size of the propagules is a key trait that can be important for the colonization process ${ }^{22}$. In the one hand, it has a significant influence in their dispersal ${ }^{23}$ mainly because larger propagules will be less likely to travel over long distances. However, large propagule sizes are not constrained solely to local colonization (e.g. refs. 18, 20, 24, 25), and small propagule sizes can also be related with mostly local expansions ${ }^{21,26,27}$. Viable bryophyte fragments have been trapped from air with high abundances at long distances from their natural distribution area ${ }^{18,28-30}$, or in areas with very restricted occurrences ${ }^{31}$, and also attached to animals ${ }^{32-35}$ (see also a thorough revision in ref. 35), or even dispersed by humans ${ }^{36,37}$. Furthermore, relatively large moss cushion patches detached from the substrate can also act as colonization vehicles ${ }^{38}$. On the other hand, it is likely that the size of the vegetative propagules is important not only for dispersal but also for the establishment success. This is a well-known trade-off for seed plants, where smaller seeds tend to have less potential for a successful establishment. Smaller seeds have lower survival rates and emergence capabilities per seed, as they have less nutrient reserves than larger seeds ${ }^{39}$. Particularly, in bryophytes, it is expected that larger propagules will have a higher establishment potential, as they may include a larger number of totipotent cells. This also happens between different types of propagules, as spores seems to have less viability than vegetative fragments ${ }^{18,40}$. However, there might be large differences among species, as not all species are equally successful in reproducing from leaves and shoots ${ }^{11,18}$. Besides, other factors could interact with size, although, for example, it is unknown if the presence and/or abundance of meristems on the vegetative 
propagules enhances their germination potential. In addition to size, propagule shape can also be important for establishment success. In vascular plants, relatively spherical dispersal structures (seeds, fruits, etc.) tend to live longer in the seed bank ${ }^{41}$. However, no previous study has directly addressed the effect of the shape of the propagules on their establishment success in mosses.

Despite the interest of the establishment stage for understanding plant colonization dynamics, the knowledge about establishment potential in bryophytes is scarce. Most studies analysing establishment in bryophytes approach it indirectly by studying invasiveness (e.g. ref. 42), or analysing particular contexts such as post-fire dynamics (e.g. refs. 43,44 ) or restoration ${ }^{45}$. Only a few experimental studies have directly quantified moss establishment (e.g. refs. $7,18,40,46)$. Consequently, there is an important knowledge gap on the interspecific and intraspecific variability of establishment success in mosses. Thus, to better understand and predict the outcome of colonization processes and quantify their importance for evolutionary biology and applied ecology, we need to improve our knowledge on the intraspecific variability and the interspecific differences in the establishment potential of vegetative fragments.

In this work we used artificially fragmented vegetative propagules of six soil moss species to study: 1 ) the variation of their establishment success as a function of the propagule size; 2) the influence of some morphological traits of the propagules; and 3) the importance of interspecific differences in the establishment success. To do this, we cultured artificially-obtained fragments in the top surface of rockwool cubes to analyse their establishment and colonization success under controlled conditions, recording the number of established propagules in a given area, and the cover surface and biomass of the resulting moss patches after colonization. For each species, we characterized the range of sizes, projected area and morphological type of its propagules. Specifically, we studied Dicranum scoparium Hedw., Homalothecium aureum (Spruce) H. Rob., Hypnum cupressiforme Hedw., Ptychostomum capillare (Hedw.) D.T. Holyoak \& N. Pedersen (= Bryum capillare Hedw.), Syntrichia ruralis F. Weber \& D. Mohr and Tortella squarrosa (Brid.) Limpr. (= Pleurochaete squarrosa (Brid.) Lindb.) These species were selected because they are all soil species - which are usually easier to cultivate-; have similarly broad distributions but co-occur in several regions; and are common in Europe, while showing different ecological and habitat preferences (e.g. types of soil, humidity gradient), and adaptive growth strategies (e.g. mode of branching), thus providing insights on the functional diversification of moss responses.

\section{Material And Methods}

\section{Study species}

The moss species studied have widespread distributions that span several continents ${ }^{47,48}$. All six species are common in the Iberian Peninsula, where they frequently coexist (e.g. refs. 52, 55). They differ in ecological requirements regarding humidity ( $D$. scoparium is hygrophyte-mesophyte, $H$. cupressiforme and $P$. capillare are mesophyte-xerophytes and $H$. aureum, $S$. ruralis and $T$. squarrosa are xerophytes) and soil type (e.g. D. scoparium and P. capillare are more humicolous, and $H$. aureum is more arenicolous) 
(see ref. 47). Besides, they also differ in their bearing of archegonia and growth form; $H$. aureum and $H$. cupressiforme are pleurocarpous mosses that grow flat to the ground, whereas P. capillare, S. ruralis, $T$. squarrosa and $D$. scoparium are acrocarpous species that grow normally erect. Additionally, $P$. capillare can develop specialized asexual propagules in rhizoids, stems and leaves ${ }^{56}$.

\section{Experimental design}

The study consisted of two experiments, a pilot experiment to test different methods of artificial fragmentation and experimental conditions, and the main experiment, in which we tested the effect of propagule size on the establishment success.

In the pilot experiment we tested the six species, two different substrates (rockwool $v s$. felt), and four classes of fragments (fragments resulting from wet milling, and three size intervals of dry-milled fragments). We tested three replicates of all combinations ( 6 species $\times 2$ substrates $x 4$ fragment types), thus we had a total sample size of 144 . For wet milling, we first saturated the samples with water and milled them for 10 seconds in a regular electric coffee grinder with a single blade. Note that wet milling does not allow the separation of fragments of different size, and it may affect survival rates. For dry milling, we air-dried the samples and milled them in several successive steps until we obtained enough material of the different propagule size classes. To separate the fragments by size we sieved the drymilled propagules through meshes of different size (small: $\varnothing 0.25 \mathrm{~mm}-0.16 \mathrm{~mm}$, medium: $\varnothing 0.45 \mathrm{~mm}$ $0.25 \mathrm{~mm}$, large: $\varnothing 0.75 \mathrm{~mm}-0.63 \mathrm{~mm}$ ). This method separates propagules by their maximum width but note that propagules can substantially vary in length, especially in the cases of long and narrow propagules. The propagules were sown in $4 \times 4 \mathrm{~cm}$ seedling pots and kept in a growth chamber in controlled conditions (temperature of $10{ }^{\circ} \mathrm{C}$, photoperiod $10 / 12 \mathrm{~h}$, and a PAR radiation light of $31 \mu \mathrm{mol} \mathrm{m}$

$\left.{ }^{2} \mathrm{~s}^{-1}\right)$, for 8 weeks. The results of the pilot experiment showed that there were no substantial differences between the establishment success of wet and dry fragments. Since dry milling allowed an easy separation of propagules by size, we used this milling method in the main experiment. Also, we used rockwool as a substrate because it is an inert material that does not interfere with growth and required less watering.

The main experiment consisted of a full factorial design including as factors the 6 species and three size classes of dry-milled fragments (small: $\varnothing 0.25 \mathrm{~mm}-0.16 \mathrm{~mm}$, medium: $\varnothing 0.45 \mathrm{~mm}-0.25 \mathrm{~mm}$, large: $\varnothing$ $0.75 \mathrm{~mm}-0.63 \mathrm{~mm}$ ). Total sample size for the main experiment was 216 ( 6 species $x 3$ fragment sizes $x$ 12 replicates). Each sample consisted of $0.004 \mathrm{~g}( \pm 0.0002 \mathrm{~g})$ of fragments sown in a $5 \times 5 \mathrm{~cm}$ pot filled with rockwool. The experiment was done in the same culture conditions as the pilot experiment. The plants were allowed to grow for 2 months. At the end of the experiments, we made a qualitative assessment on the germination of the species observing whether the established shoots arose from leaf or shoot fragments.

We measured several parameters at the end of the experiment as indicators of establishment success: the number of established shoots, the percentage of surface covered by the established shoots in relation 
to the sample surface (colonized surface), the biomass of the established shoots (viable biomass) and non-viable biomass (non-established shoots and the rest of organic matter). Biomass was weighted after collecting and oven-drying the established shoots at $60^{\circ} \mathrm{C}$ for $48 \mathrm{~h}$. The biomass data (both viable and no viable biomass, which account for final biomass) was used to estimate the percentage of viable biomass respect to the cultured biomass and the Relative Growth Rate (RGR), calculated as follows:

$$
\text { Viable biomass }(\%)=\frac{\text { Viable biomass }}{\text { Cultured Biomass }} \times 100
$$

$$
\text { Relative Growth Rate }=\frac{(\ln \text { Final biomass }(g)-\ln \text { Cultured biomass }(g)}{\text { Time }(\text { month })} \quad \text { [Eq.2] }
$$

These indicators account for local population growth as in Söderström \& Herben (1997), taking into account that the shoots can be newly generated during the culture period, or be already present in the cultured propagules. This formula allows focusing only on newly generated biomass.

\section{Propagule trait characterization}

To characterize the traits of the propagules, we measured 30 propagules of each species and fragment size class (540 propagules in total) under the optical microscope. First, we annotated several morphological traits in hydrated state. Then, we calculated the proportion of shoots per every propagule size class, as it is known that shoots have greater germination potential than leaves ${ }^{18}$. Afterwards, we measured a viability index (hereafter apparent viability) according to some observable features, and assigning each propagule to values from 1 (large number of collapsed cells, apparent senescence) to 6 (few empty/collapsed cells, cytoplasm with plastids) in an ordinal scale. Additionally, we measured several quantitative size and shape traits in dry and hydrated states. For this purpose, we took photos of the same set of propagules, both dry and hydrated, and analysed the images using the software Image $\mathrm{J}^{58}$. We measured the area of the propagules in $\mathrm{mm}^{2}$; the maximum length in $\mathrm{mm}$ and the circularity, a shape descriptor that is size-independent and varies between 0 and 1, 1 being a perfect circle. Additionally, we compared the area (Equation 3) and maximum length (Equation 4) of hydrated and dry propagules:

$$
\begin{gathered}
\text { Wet vs.dry area }=\frac{\text { Area of hydrated propagule }- \text { Area of dry propagule }}{\text { Area of hydrated propagule }} \quad[\text { [Eq.3] } \\
\text { Wet vs dry length }=\frac{\text { Length of hydrated propagule-Length of dry propagule }}{\text { Length of hydrated propagule }} \\
\text { [Eq.4] }
\end{gathered}
$$


To select the most relevant propagule traits we explored the correlations between the studied traits and the establishment success indicators using a correlogram and a network plot. The $p$-values of the correlations were adjusted using post hoc Holm adjustment method.

We used analysis of deviance (Type III test) to determine the effects of 1 ) propagule size (classes large, medium and small), 2) species cultured (D. scoparium, $H$. aureum, $H$. cupressiforme, $P$. capillare, $S$. ruralis and $T_{\text {._squarrosa) }}$ and 3 ) the interaction between these two factors on colonization. We measured establishment by using four indicators as dependent variables in the different analyses: number of established shoots, colonized surface, viable biomass and relative growth rate (RGR). We tested the deviations from normality and homoscedasticity of model residuals using Kolmogorov-Smirnov and Bartlett's tests for the main effects, and Levene's tests for the interactions. Since the tests showed large deviations from normality, we used robust models with IWLS (iteratively (re)weighted least squares) for all the indicators, and a box-cox transformation on number of established shoots, colonized surface and viable biomass, to cope with the violations of normality in these variables. Also, we used a type III analysis of variance with HC4 (heteroscedasticity-consistent) robust sandwich variance estimator to cope with heteroscedasticity for all the indicators. RGR transformation was not need, being enough with the robust model and robust sandwich estimator. Then, we performed planned contrasts for post hoc pairwise t-tests with Holm adjustment method for the $p$-values, to assess properly the interactions between the two factors. Finally, after adjusting the models we assessed that there was no overdispersion in the data. All statistical analyses and graphs were performed in R environment ${ }^{59}$, using the packages:

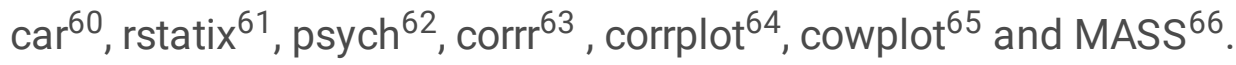

\section{Results}

\section{Establishment success}

All studied species were able to establish successfully from vegetative propagules. Even so, there were differences among the species in all indicators of successful establishment. Propagule size was a key factor regulating establishment success for all species. Larger propagule size classes tend to have greater establishment success (Figure 1). However, there was a large interspecific variability in the establishment success of the propagules. The variability explained by the species, propagule size and their interaction was high for all the indicators of establishment success, but especially so for the number of established shoots and the colonized surface, where it was above 0.85 (Table 1).

Table 1. Results of the analysis of deviance testing the effect of species, propagule size and their interaction on the indicators of establishment success (number of established shoots, colonized surface, viable biomass and relative growth rate). $\mathrm{R}^{2}$ indicates the proportion of variance explained by the model including all three predictors. 
Response variable

Number of established shoots

Colonized

surface

Viable

biomass

Relative growth

rate

Treatments

\begin{tabular}{|c|c|c|c|c|}
\hline Species & 374.54 *** & $177.3 * \star \star$ & 154.3 *** & 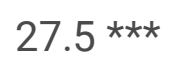 \\
\hline Propagule size & 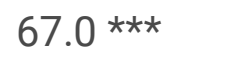 & $111.5^{* \star \star}$ & $260.5^{\star * \star *}$ & 116.8 *** \\
\hline $\begin{array}{l}\text { Species } \mathrm{x} \text { propagule } \\
\text { size }\end{array}$ & 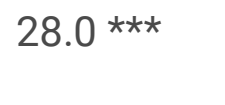 & 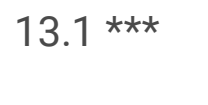 & 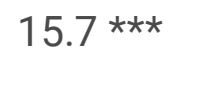 & $5.7 * \star \star$ \\
\hline $\mathrm{R}^{2}$ & 0.90 & 0.85 & 0.79 & 0.59 \\
\hline
\end{tabular}

Overall, the magnitude of the interspecific differences of all indicators of establishment success was larger at the smaller propagule size class (Figure 1). This implies that species differed largely in their ability to establish from small propagules. Also, the effect of propagule size varied with the indicator of establishment success. Regarding the number of established shoots, $D$. scoparium showed generally low numbers that decreased with propagule size, so that the smallest propagule size class presents the lowest number of established shoots in this species (Figure 1). H. cupressiforme and S. ruralis showed an intermediate number of established shoots for the larger propagule size and a moderate decrease in the number of established shoots in the smallest propagule size. In contrast, $H$. aureum and $P$. capillare showed an intermediate number of established shoots that was similar in the three propagule size classes, while $T$. squarrosa showed high numbers of this indicator in all three propagule size classes. The response was very similar for the colonized surface (Figure 1). However, the species showed a different pattern when considering the production of viable biomass and relative growth rate (RGR). For viable biomass, $D$. scoparium showed low values for all the propagule size classes (Figure 1). While the rest of the species showed a decrease in the number of established shoots corresponding with smaller propagules, this decrease was sharper in $H$. cupressiforme and S. ruralis than in the rest of the species. Finally, RGR showed three different patterns (Figure 1). Both D. scoparium and H. cupressiforme showed low RGR in all propagule size classes. In turn, H. aureum, P. capillare and $S$. ruralis showed a moderate decrease in RGR in the smaller propagule sizes. Finally, in T. squarrosa we observed a subtle decrease in RGR values with the decrease in propagule size and moderate RGR values in all propagule sizes. In general terms, there seemed to be no association between establishment success and life history traits or ecological requirements (see Methods and Figure 1).

The six species studied showed heterogeneity in propagule traits (Table 2) and among propagule sizes (Tables S.2 and S.3). There was a very large interspecific variation in the percentage of shoots of the propagules. P. capillare showed the highest proportion of shoots, well above $80 \%$. In the other end, $T$. squarrosa and S. ruralis showed the lowest proportion of shoots, below $25 \%$. In contrast, the apparent viability of the propagules before culture did not show much variation among species. The average area of the propagules varied between the $0.69 \mathrm{~mm}^{2}$ of $P$. capillare and the $2.48 \mathrm{~mm}^{2}$ of $D$. scoparium. 
Similarly, there was a large amount of interspecific variability in the length of the propagules. $D$. scoparium had the longest propagules followed by $T$. squarrosa and $S$. ruralis. Concerning the shape, the species were more similar than in size traits. Most propagules in all six species were elongated in shape rather than circular, with circularity values between 0.32 and 0.48 . Finally, all species showed a considerable increase in propagule area when the propagules were wet. This increase was maximum for the propagules of $S$. ruralis and $T$. squarrosa. The differences in length by hydration states were also subtle. When wet, the propagules of $D$. scoparium, $H$. aureum and $H$. cupressiforme did not elongate substantially, while the propagules of $P$. capillare, $S$. ruralis and $T$. squarrosa showed a moderate elongation.

Some of these traits were significantly correlated (Figures 2 and S1), pointing to the existence of syndromes of associated traits. Unsurprisingly, the highest correlations occurred between the size-related traits, and so, the propagules with larger area were also longer, and the propagules that increased more their area in wet also elongated more in wet conditions. There was a correlation between the shape and the size of the propagules, as larger propagules tended to be more elongated (lower circularity values). Interestingly, the proportion of shoots was larger in larger propagules classes (not shown).

Table 2. Summary of the average values and standard deviations of the size and shape traits for the six analysed species

\begin{tabular}{|c|c|c|c|c|c|c|c|}
\hline Species & $\begin{array}{l}\text { Shoot } \\
\%\end{array}$ & $\begin{array}{l}\text { Apparent } \\
\text { viability }\end{array}$ & $\begin{array}{l}\text { Area } \\
\left(\mathrm{mm}^{2}\right)\end{array}$ & $\begin{array}{l}\text { Length } \\
(\mathrm{mm})\end{array}$ & Circularity & $\begin{array}{l}\text { Wet vs. } \\
\text { dry area }\end{array}$ & $\begin{array}{l}\text { Wet vs. } \\
\text { dry length }\end{array}$ \\
\hline D. scoparium & 52.2 & $\begin{array}{l}5.16( \pm \\
1.54)\end{array}$ & $\begin{array}{l}2.48( \pm \\
2.46)\end{array}$ & $\begin{array}{l}3.08( \pm \\
1.67)\end{array}$ & $\begin{array}{l}0.34( \pm \\
0.15)\end{array}$ & $\begin{array}{l}0.31( \pm \\
0.15)\end{array}$ & $\begin{array}{l}0.06( \pm \\
0.11)\end{array}$ \\
\hline H. aureum & 51.1 & $\begin{array}{l}5.39( \pm \\
1.28)\end{array}$ & $\begin{array}{l}1.14( \pm \\
1.34)\end{array}$ & $\begin{array}{l}1.90( \pm \\
1.18)\end{array}$ & $\begin{array}{l}0.33( \pm \\
0.16)\end{array}$ & $\begin{array}{l}0.35( \pm \\
0.18)\end{array}$ & $\begin{array}{l}0.07( \pm \\
0.12)\end{array}$ \\
\hline $\begin{array}{l}\text { H. } \\
\text { cupressiforme }\end{array}$ & 41.1 & $\begin{array}{l}5.28( \pm \\
1.41)\end{array}$ & $\begin{array}{l}0.80( \pm \\
0.88)\end{array}$ & $\begin{array}{l}1.56( \pm \\
0.79)\end{array}$ & $\begin{array}{l}0.43( \pm \\
0.15)\end{array}$ & $\begin{array}{l}0.24( \pm \\
0.30)\end{array}$ & $\begin{array}{l}0.03( \pm \\
0.22)\end{array}$ \\
\hline P. capillare & 81.1 & $\begin{array}{l}4.82( \pm \\
1.61)\end{array}$ & $\begin{array}{l}0.69( \pm \\
0.53)\end{array}$ & $\begin{array}{l}1.49( \pm \\
0.66)\end{array}$ & $\begin{array}{l}0.48( \pm \\
0.17)\end{array}$ & $\begin{array}{l}0.31( \pm \\
0.17)\end{array}$ & $\begin{array}{l}0.12( \pm \\
0.09)\end{array}$ \\
\hline S. ruralis & 17.7 & $\begin{array}{l}5.44( \pm \\
1.08)\end{array}$ & $\begin{array}{l}1.46( \pm \\
1.26)\end{array}$ & $\begin{array}{l}2.39( \pm \\
1.45)\end{array}$ & $\begin{array}{l}0.46( \pm \\
0.15)\end{array}$ & $\begin{array}{l}0.48( \pm \\
0.20)\end{array}$ & $\begin{array}{l}0.14( \pm \\
0.13)\end{array}$ \\
\hline T. squarrosa & 23.3 & $\begin{array}{l}5.62( \pm \\
0.88)\end{array}$ & $\begin{array}{l}1.12( \pm \\
0.73)\end{array}$ & $\begin{array}{l}2.42( \pm \\
0.91)\end{array}$ & $\begin{array}{l}0.32( \pm \\
0.17)\end{array}$ & $\begin{array}{l}0.54( \pm \\
0.13)\end{array}$ & $\begin{array}{l}0.34( \pm \\
0.16)\end{array}$ \\
\hline
\end{tabular}

In general, all establishment success indicators, except circularity and area, were positively correlated with propagule traits (Figure 2). Relative Growth Rate (RGR) showed significant correlations with more traits than the rest of the establishment success indicators. The two traits related to the size increase of wet versus dry propagules showed the highest correlations with establishment success (relative growth rate, number of established propagules and colonized surface). The proportion of established shoots was the only trait correlated to the viable biomass. 


\section{Discussion}

Our results show that propagule size alone is not a good predictor of establishment success, and other traits such as the capacity of hydration or propagule length need to be considered in this regard. These results stand out despite the large interspecific differences in the effect of propagule size on success. For example, Dicranum scoparium had the largest propagule area and the lowest establishment success while Ptychostomum capillare had the smallest propagule area and a relatively high establishment success. These results imply the lack of an overall trade-off between propagule size and establishment success in the vegetative propagules of bryophytes. However, our experiments evidence that propagule size is critical for establishment success at the intraspecific level, as the smallest propagules had a reduced establishment success at least for one of the indicators in all species.

Many cells in the vegetative body of bryophytes are not irreversibly differentiated, and thus are able to produce a new plant ${ }^{17}$. Therefore, it could be argued that the larger a propagule is and the higher the number of cells it contains, the higher the potential of successful establishment would be. However, this is only true if all the cells have a similar regenerative potential. Literature on the development from vegetative cells in bryophytes is sparse and for most species it is unknown whether the regeneration from any vegetative cell is possible or not (but see ref. 16). The few previous studies suggest the existence of large differences in the regeneration potential between different species and plant tissues (e.g. ref. 40). For example, regeneration from leaves has been described only in a few species while regeneration from shoots seems to be more common (e.g. ref. 18). Our results confirm these interspecific differences in regeneration potential, as the lack of a consistent relationship between size and establishment success may be due to a different degree of specialization in their ability to reproduce from vegetative tissues. Our qualitative observations also point in this direction. We identified only two species that could routinely regenerate from leaves ( $T$. squarrosa and $P$. capillare), while in the rest of the species regeneration occurred mostly from shoots. Other intermediate strategies were found in other species, where in leafy fragments and individual leaves, some small part or strip of the stem was enough to make the propagule germinate, acting the leaf as vehicles for dissemination ${ }^{18}$.

This panorama is completely different at the intraspecific level, as the smallest propagules show reductions in one or more indicators (i. e. number of established shoots, colonized surface, viable biomass or relative growth rate), and some species, such as $D$. scoparium, have significant difficulties in establishing from very small propagules. Further, all species responded decreasing their biomass production and RGR as propagule size decreased. Strikingly, the very small propagules are more likely to disperse far from the source, so they are key for making a reliable assessment on the large-distance colonization potential of the species. Indeed, the analysed species showed two types of responses to propagule size. On the one hand, species in which propagule size had a null or small effect on the establishment success ( $T$. squarrosa and to some extent also $H$. aureum and $P$. capillare); note also that $H$. aureum and $T$. squarrosa did not show such decreasing trend in colonized surface and number of established shoots. On the other, species in which propagule size had a strong negative effect on establishment success (D. scoparium, Hypnum cupressiforme and Syntrichia ruralis). Further refinement 
of this classification can be obtained by considering the overall establishment success, from $T$. squarrosa, the most successful species, to the very low success of $D$. scoparium. In fact, the low success of $D$. scoparium was striking and it might be related to the low resistance of the species to the fragmentation disturbance or to an absence of the necessary fungal communities in lab conditions (see ref. 67).

Interestingly, some of the analysed traits showed a positive association with establishment success. In particular, wet to dry area and propagule length showed the highest species-independent correlation with success. The mechanistic explanation for such importance of hydration is not straightforward, but deserves further study because of its strong adaptive implications: the species with propagules that expand substantially in wet can afford relatively small propagules with a larger potential for long distance dispersal in dry. At the same time these propagules in the wet conditions that are favourable for establishment will expand substantially occupying more surface. In this experiment, larger differences between hydric states were found in species with leafy type fragments, which were predominant in both $S$. ruralis and $T$. squarrosa, the two species with largest changes in area between hydric states. Note, however, that many bryophyte species can be favoured by this strategy (e.g., table S.2 of this study), not only the ones able to reproduce vegetatively from leaves as $T$. squarrosa or $S$. ruralis (with also more proportion of leaves when fragmented, see shoot percentage in Table 2). The species that commonly break into leafy fragments can also reproduce from a small strip of shoot material attached to the leaf part of the fragment ${ }^{18}$. This strategy may be straightforward for some species, whereas in other species hydration is critical before fragmentation ${ }^{68}$. Note that, even so, later dehydration of the wet fragmented propagules can result in the same strategy, so this can be a general process for most soil moss species. Furthermore, these vegetative fragments may respond adaptively to well-known characteristics of mosses, such as mosses particular moisture-desiccation dynamics based on two key mechanisms: constitutive cellular protection to desiccation and recovery after rehydration 69,70 .

This information discussed, however, confront partially with historically attributions of dispersal of vegetative fragments. In dispersal and establishment of propagules, wind speed, temperature and air moisture may play an important role ${ }^{27}$. Vegetative fragments are normally associated to local maintenance or local expansions in the populations of mosses, being diminished their relevance in wind dispersal and long distance dispersal ${ }^{18}$, normally associated to spores. However, whereas tolerance to long distance dispersal in spores has been addressed and questioned ${ }^{71}$, moisture - desiccation dynamics in vegetative fragments could make vegetative fragments better candidates than thought before for success in wind and long dispersal.

Our results imply that propagule size alone cannot be used as a surrogate of establishment success. This, in turn, complicates the quantification of the importance of vegetative propagation for evolutionary biology and applied ecology applications. Furthermore, we found no association between establishment success and life history traits (pleurocarpous vs. acrocarpous) or taxonomic affinity. However, our study was not specifically designed to test hypotheses related to life history or taxonomic affinity thus their lack 
of importance needs further confirmation. In turn, we contribute unveiling several relevant traits, such as shoot percentage, apparent viability, length and wet versus dry area and length, that in our experiments showed a positive association with establishment success and hence to individual fitness. Even so, it is also remarkable that while fragmentation is considered specially common among pleurocarpous mosses ${ }^{11}$, acrocarpous mosses in this study ( $T$. squarrosa and $S$. ruralis) also exhibited a different proportion of types of propagules produced after fragmentation (except $P$. capillare, tables 1 and S.3, most of them shoots). This led us to question whether the proportion of fragments of different nature produced after fragmentation is a particular characteristic of the species. Clarifying this is relevant due to the implications at all stages in colonization, as establishment success vary among propagule types ${ }^{40}$. For example, in some species leaves produce gemmae, propagules smaller than shoots, being able to dispersal across longer distances ${ }^{11}$ (also this study), while others do not. These basic differences may become an ecological filter with implications for metapopulation dynamics and community assembly, particularly during recolonization processes.

To summarize, our results show that the vegetative establishment potential in mosses responds to propagule size. However, propagule size alone is not enough to assess such potential due to the large interspecific variability. Several of the traits we analysed, in combination with propagule size, affect establishment potential. The combination of wet to dry area, percentage of shoots after fragmentation and apparent viability determine species syndromes that have not described before, which we hypothesize may play an important role in the colonization of new habitats by soil mosses. Given the lack of a unique proxy for vegetative establishment success, and the large interspecific differences, further systematic measures that allow interspecific comparisons are needed to advance our knowledge.

\section{Declarations}

\section{ACKNOWLEDGEMENTS}

To Elisa Garzo González, for her support and tips with the acclimatized chambers, to Cristina Ronquillo for her help during the processing of the samples and to Luis María Carrascal for his assistance with several $\mathrm{R}$ analyses.

\section{PLANT COLLECTION STATEMENT}

All specimens were identified by NGM, BE, FH and MM-B, and voucher specimens of all samples from the six species were deposited at MAUAM herbarium at the Universidad Autónoma de Madrid, Spain. All mosses were collected under permission of the Comunidad de Madrid, Dirección General de Medio Ambiente, reference 10/112725.9/19. All sampling locations are public lands, or public accesseasements, so no permissions were required from land owners.

AUTHOR CONTRIBUTIONS STATEMENT:

Methodology and conceptualization: FH, BE, NGM, JH and PA 
Sampling and identification of the species: NGM, BE, MM-B and FH

Resources: BE, JH and NGM

Investigation: $\mathrm{FH}, \mathrm{NGM}, \mathrm{BE}$ and MM-B

Formal analysis and supervision of the analysis: FH, NGM, BE, PA and JH

Elaboration, revision of the manuscript and constant feedback: FH, NGM, BE, JH and PA

Project administration and funding acquisition: JH, PA and NGM

\section{DATA STATEMENT}

All data will be uploaded to DIGITAL.CSIC public repository upon acceptance of the article.

\section{References}

1. Ebenhard, T. Colonization in metapopulations: a review of theory and observations. Biol. J. Linn. Soc. 42, 105-121 (1991).

2. Szucs, M., Melbourne, B. A.., Tuff, T. \& Hufbauer, R. A. The roles of demography and genetics in the early stages of colonization. Proc. R. Soc. B Biol. Sci. 281, (2014).

3. Williamson, M. Biological Invasions, Vol. 15. (Springer Science \& Business Media., 1996).

4. Dai, Z. C. et al. Synergy among hypotheses in the invasion process of alien plants: A road map within a timeline. Perspect. Plant Ecol. Evol. Syst. 47, 125575 (2020).

5. Briski, E. et al. Beyond propagule pressure: importance of selection during the transport stage of biological invasions. Front. Ecol. Environ. 16, 345-353 (2018).

6. Li, Y. \& Vitt, D. H. The Dynamics of Moss Establishment: Temporal Responses to Nutrient Gradients. Bryologist 97, 357-364 (1994).

7. Li, Y. \& Vitt, D. H. The dynamics of moss establishment: Temporal responses to a moisture gradient. J. Bryol. 18, 677-687 (1995).

8. Wiklund, K. \& Rydin, H. Ecophysiological constraints on spore establishment in bryophytes. Funct. Ecol. 18, 907-913 (2004).

9. Zanatta, F. et al. Bryophytes are predicted to lag behind future climate change despite their high dispersal capacities. Nat. Commun. 11, (2020).

10. Seaborn, T. J., Goldberg, C. S. \& Crespi, E. J. Integration of dispersal data into distribution modeling: What have we done and what have we learned? Front. Biogeogr. 12, 1-14 (2020).

11. Glime, J. M. Bryophyte Ecology (Vol. 1, Issue Physiological Ecology, Chap. 4-10 Adaptive Strategies: Vegetative Propagules, pp. 1-44). (2021).

12. Guerra, J., Brugués, M., Cano, M. J. \& Cros, R. M. Bryum Hedw. in Flora Briofítica Ibérica, Vol. IV, Funariales, Splachnales, Schistostegales, Bryales, Timmiales (eds. Brugués, M. \& Cros, R. M.) 105- 
178 (Universidad de Murcia. Sociedad Española de Briología, 2010).

13. Medina, N. G., Draper, I. \& Lara, F. Biogeography of mosses and allies: Does size matter? in Biogeography of Microscopic Organisms: is Everything Small Everywhere? 209-233 (2011). doi:10.1017/СВ09780511974878.012

14. Miles, C. J. \& Longton, R. E. The role of spores in reproduction in mosses. Bot. J. Linn. Soc. 104, 149-173 (1990).

15. Pérez, B. E., Draper y Díaz de Atauri, I. \& Bujalance, R. M. Bryophytes: an approximation to the simplest land plants. in Biodiversidad. Aproximación a la diversidad botánica y zoológica de España 19, (2011).

16. Giordano, S. et al. Regeneration from detached leaves of Pleurochaete squarrosa (Brid.) Lindb. in culture and in the wild. J. Bryol. 19, 219-227 (1996).

17. La Farge, C., Williams, K. H. \& England, J. H. Regeneration of Little Ice Age bryophytes emerging from a polar glacier with implications of totipotency in extreme environments. Proc. Natl. Acad. Sci. U. S. A. 110, 9839-9844 (2013).

18. Robinson, S. C. \& Miller, N. G. Bryophyte diversity on Adirondack alpine summits is maintained by dissemination and establishment of vegetative fragments and spores. Bryologist 116, 382-391 (2013).

19. Glime, J. M. Chapter 2 - 1 Meet the bryophytes. in Bryophyte Ecology 1, (2020).

20. Korpelainen, H., Pohjamo, M. \& Laaka-Lindberg, S. How efficiently does bryophyte dispersal lead to gene flow? J. Hattori Bot. Lab. 205, 195-205 (2005).

21. Schuster, R. M. Phytogeography of the Bryophyta. in New Manual of Bryology 1, 463-626 (Hattori Bot. Lab, 1983).

22. Löbel, S., Schröder, B. \& Snäll, T. Projected shifts in deadwood bryophyte communities under national climate and forestry scenarios benefit large competitors and impair small species. J. Biogeogr. 1-15 (2021). doi:10.1111/jbi.14278

23. Laaka-Lindberg, S., Korpelainen, H. \& Pohjamo, M. Dispersal of asexual propagules in bryophytes. J. Hattori Bot. Lab. 330, 319-330 (2003).

24. Miller, N. G. \& Mogensen, G. S. Cyrtomnium hymenophylloides (Bryophyta, Mniaceae) in North America and Greenland: Male plants, sex-differential geographical distribution, and reproductive characteristics. Bryologist 100, 499-506 (1997).

25. Muñoz, J., Felicísimo, Á. M., Cabezas, F., Burgaz, A. R. \& Martínez, I. Wind as a Long-Distance Southern Hemisphere. 304, (2004).

26. Patiño, J. \& Vanderpoorten, A. Bryophyte Biogeography. CRC. Crit. Rev. Plant Sci. 37, 175-209 (2018).

27. Pasiche-Lisboa, C. J., Booth, T., Belland, R. J. \& Piercey-Normore, M. D. Moss and lichen asexual propagule dispersal may help to maintain the extant community in boreal forests. Ecosphere 10, (2019). 
28. Barbé, M., Fenton, N. J. \& Bergeron, Y. So close and yet so far away: long-distance dispersal events govern bryophyte metacommunity reassembly. J. Ecol. 104, 1707-1719 (2016).

29. Hansson, L., Söderström, L. \& Solbreck, C. The Ecology of Dispersal in Relation to Conservation. in Ecological Principles of Nature Conservation. Conservation Ecology Series: Principles, Practices and Management. (ed. Hansson, L.) (Springer, 1992). doi:10.1007/978-1-4615-3524-9

30. Miller, N. G. \& Ambrose, L. J. H. Growth in Culture of Wind-Blown Bryophyte Gametophyte Fragments from Arctic Canada. Bryologist 79, 55 (1976).

31. Barbé, M., Fenton, N. J., Caners, R. \& Bergeron, Y. Inter-annual variation in bryophyte dispersal: linking bryophyte phenophases and weather conditions. Botany 95, 1151-1169 (2017).

32. Chmielewski, M. W. \& Eppley, S. M. Forest passerines as a novel dispersal vector of viable bryophyte propagules. Proc. R. Soc. B Biol. Sci. 286, (2019).

33. Davison, G. W. H. Role of birds in moss dispersal. Br. birds 69, 65-66 (1976).

34. Heinken, T., Lees, R., Raudnitschka, D. \& Runge, S. Epizoochorous dispersal of bryophyte stem fragments by roe deer (Capreolus capreolus) and wild boar (Sus scrofa). J. Bryol. 23, 293-300 (2001).

35. Parsons, J. G. et al. Bryophyte dispersal by flying foxes: A novel discovery. Oecologia 152, 112-114 (2007).

36. Glime, J. M. Bryophyte Ecology (Vol. 2, Issue Bryological Interaction). (2021).

37. Ware, C., Bergstrom, D. M., Müller, E. \& Alsos, I. G. Humans introduce viable seeds to the Arctic on footwear. Biol. Invasions 14, 567-577 (2012).

38. Shacklette, H. T. Unattached Moss Polsters on Amchitka Island, Alaska. Bryologist 69, 346-352 (1966).

39. Moles, A. T. \& Westoby, M. Seedling survival and seed size: A synthesis of the literature. J. Ecol. 92, 372-383 (2004).

40. Kimmerer, R. W. Patterns of dispersal and establishment of bryophytes colonizing natural and experimental treefall mounds in northern hardwood forests. Bryologist 108, 391-401 (2005).

41. Pérez-Harguindeguy, N. et al. New handbook for standardised measurement of plant functional traits worldwide. Aust. J. Bot. 61, 167-234 (2013).

42. Hugonnot, V. Comparative investigations of niche, growth rates and reproduction between the native moss Campylopus pilifer and the invasive C. introflexus. J. Bryol. 39, 79-84 (2017).

43. Benscoter, B. W. Post-fire bryophyte establishment in a continental bog. J. Veg. Sci. 17, 647 (2006).

44. Esposito, A., Mazzoleni, S. \& Strumia, S. Post-fire bryophyte dynamics in Mediterranean vegetation. J. Veg. Sci. 10, 261-268 (1999).

45. Naeth, M. A. \& Wilkinson, S. R. Establishment of restoration trajectories for upland tundra communities on diamond mine wastes in the Canadian arctic. Restor. Ecol. 22, 534-543 (2014).

46. Lamarre, J. J. M. Tundra bryophyte revegetation: novel methods for revegetating northern ecosystems. (University of Alberta, 2016). 
47. Dierßen, K. Distribution, ecological amplitude and phytosociological-characterization of European bryophytes. Nov. Hedwigia 74, (2001).

48. Smith, A. J. E. The moss flora of Britain and Ireland. (Cambridge University Press, 2004).

49. Brugués, M. \& Ruiz, E. Dicranum Hedw. in Flora Briofítica Ibérica. Vol. II (eds. Guerra, J. \& Brugués, M.) 105-128 (Universidad de Murcia. Sociedad Española de Briología, 2015).

50. Guerra, J., Orgaz, J. D. \& Sérgio, C. Homalothecium Schimp. in Flora Briofítica Ibérica. Vol. VI: Hypnales (eds. Guerra, J., Cano, M. J. \& Brugués, M.) 138-148 (Universidad de Murcia. Sociedad Española de Briología, 2018).

51. Ron, E., Gómez, D. \& Fernández - Mendoza, F. Pleurochaete Lindb. in Flora Briofítica Ibérica. Vol. III (eds. Guerra, J., Cano, M. J. \& Ros, R. M.) 60-63 (Universidad de Murcia. Sociedad Española de Briología, 2006).

52. Casas, C., Brugués, M., Cros, R. M. \& Sérgio, C. Handbook of Mosses of the Iberian Peninsula. (Instituts d'Estudis Catalans. Barcelona., 2006).

53. Medina, N., Mazimpaka Nibarere, V., Hortal, J. \& Lara García, F. Catálogo de los briófitos epífitos que crecen en bosques de quercíneas del cuadrante noroccidental ibérico. Boletín la Soc. Española Briología 30, 1-30 (2015).

54. Ríos, D., Gallego, M. T. \& Guerra, J. Hypnum Hedw. in Flora Briofítica Ibérica. Vol. VI: Hypnales (eds. Guerra, J., Cano, M. J. \& Brugués, M.) 336-367 (Universidad de Murcia. Sociedad Española de Briología, 2018).

55. Ron Alvarez, M. \& Vicente Orellana, J. Contribución al conocimiento de la flora briológica de Canencia, Sierra de Guadarrama (Madrid). Bot. Complut. 75-86 (1989). doi:10.5209/BOCM.7415

56. Pressel, S., Matcham, H. W. \& Duckett, J. G. Studies of protonemal morphogenesis in mosses. XI. Bryum and allied genera : a plethora of propagules. J. Bryol. 29, 241-258 (2007).

57. Söderström, L. \& Herben, T. Dynamics of bryophyte metapopulations. in Advances in Briology 6: Population Studies (ed. Longton, R. E.) 6, 205-240 (International Association of Briologists. Schweizerbart Science Publishers, 1997).

58. Schneider, C. A., Rasband, W. S. \& Eliceiri, K. W. NIH Image to Image J: 25 years of image analysis. Nat. Methods 9, 671-675 (2012).

59. R Core Team. R: A language and environment for statistical computing. (2019).

60. Fox, J. \& Weisberg, S. An R Companion to Applied Regression. (2019).

61. Kassambara, A. rstatix: Pipe-Friendly Framework for Basic Statistical Tests. (2020).

62. Revelle, W. psych: Procedures for Psychological, Psychometric, and Personality Research. (2021).

63. Kuhn, M., Jackson, S. \& Cimentada, J. corrr: Correlations in R. R package version 0.4.3. (2020).

64. Wei, T. \& Simko, V. R package 'corrplot': Visualization of a Correlation Matrix (Version 0.84). (2017).

65. Wilke, C. O. cowplot: Streamlined Plot Theme and Plot Annotations for 'ggplot2'. R package version 1.1.1. (2020).

66. Venables, N. W. \& Ripley, B. D. Modern Applied Statistics with S. (2002). 
67. Chen, K. H., Liao, H. L., Arnold, A. E., Bonito, G. \& Lutzoni, F. RNA-based analyses reveal fungal communities structured by a senescence gradient in the moss Dicranum scoparium and the presence of putative multi-trophic fungi. New Phytol. 218, 1597-1611 (2018).

68. Hugonnot, V. \& Celle, J. Asexual reproduction by leaf fragmentation in Mnium stellare Hedw. J. Bryol. 34, 67-70 (2012).

69. Oliver, M. J., Velten, J. \& Mishler, B. D. Desiccation tolerance in bryophytes: A reflection of the primitive strategy for plant survival in dehydrating habitats? Integr. Comp. Biol. 45, 788-799 (2005).

70. Proctor, M. C. F. et al. Desiccation-tolerance in bryophytes: a review. Bryologist 110, 595-621 (2007).

71. Kruijer, H. J. D., Raes, N. \& Stech, M. Modelling the distribution of the moss species Hypopterygium tamarisci (Hypopterygiaceae, Bryophyta) in Central and South America. Nov. Hedwigia 91, 399-420 (2010).

\section{Figures}
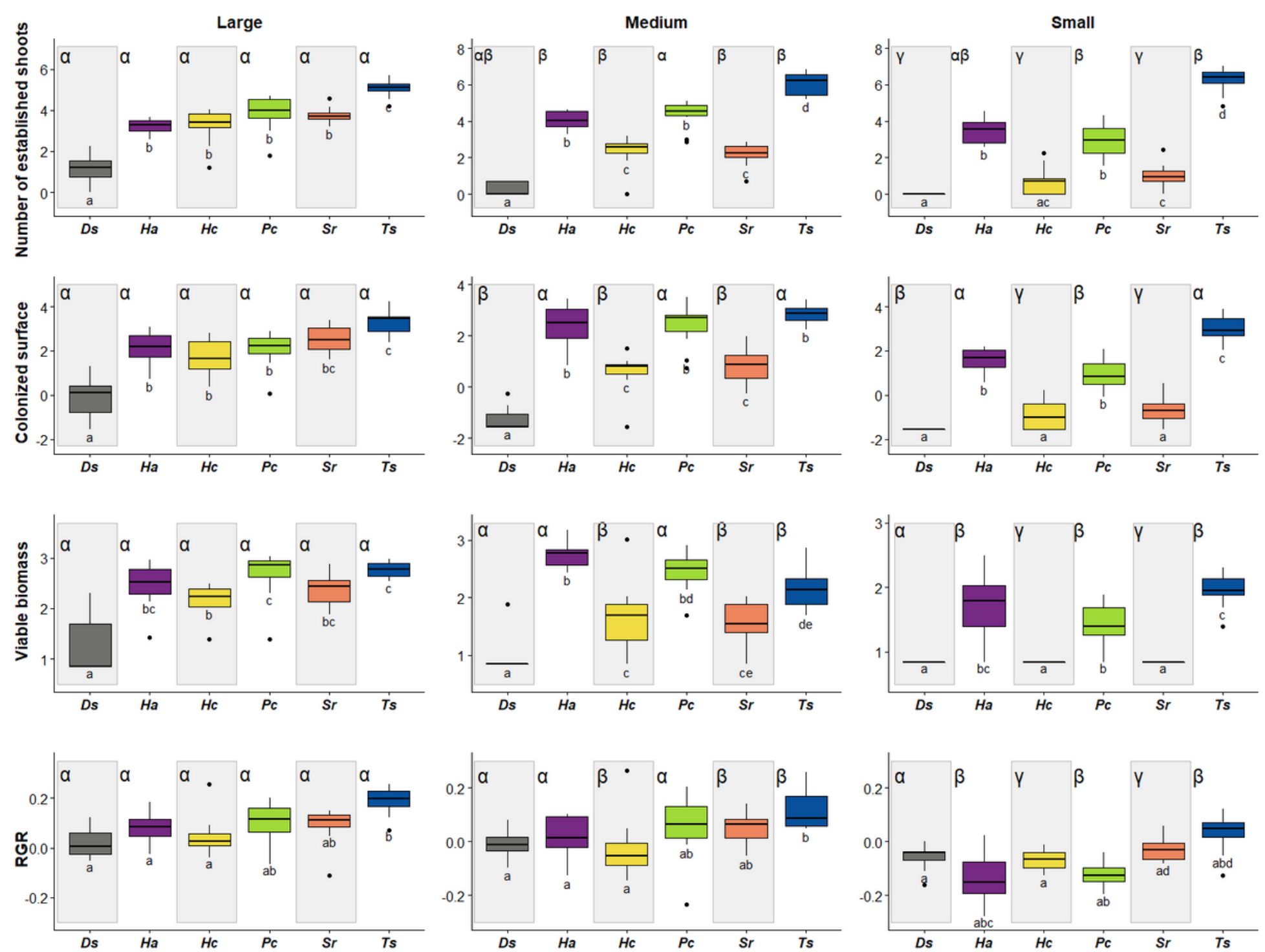

Figure 1 
Boxplots of biomass indicators for the analysed species (coloured) and propagule size classes (small, medium and large). Abbreviations: $D s$ for $D$. scoparium, $H a$ for $H$. aureum, $H c$ for $H$. crupressiforme, $P c$ for $P$. capillare, Srfor $S$. ruralis and Ts for $T$. squarrosa. Values of number of established shoots, colonized surface and viable biomass were Box-Cox transformed. Bars within each box represent the median, and boxes represent the interquartile range (IQR, top $=75$ th percentile, bottom $=25$ th percentile). Whiskers represent the largest/smallest value within 1.5 times IQR. Points represent outliers (>1.5 times IQR). Compact letter display (CLD) shown as Latin ( $a, b, c, d$ and e) and greek letters ( $a, \beta$ and $\gamma$ ) represent, respectively: 1) significant differences across species within the same propagule size, 2 ) significant differences across propagule sizes within the same species. The values for CLD assignments are the $p$ adjusted values of pairwise comparisons for planned contrasts (Tables S1.1:S1.8).
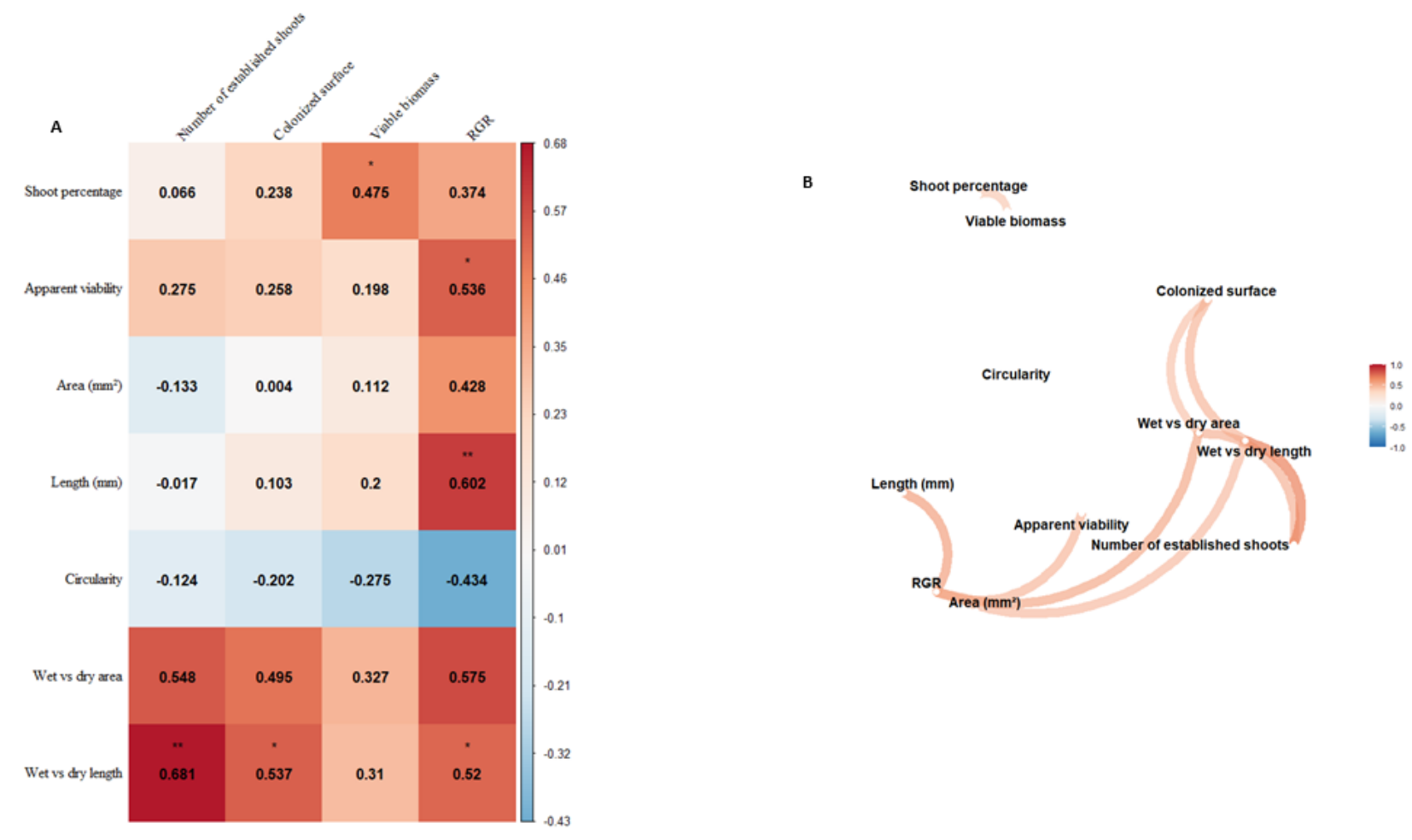

\section{Figure 2}

A) Matrix of the Pearson correlation coefficients between the analysed traits and the indicators of establishment success. Correlations vary from red (+) to blue (-). Some indicators were previously transformed (see Methods). RGR stands for Relative Growth Rate. * $p$ adjusted-values $<0.05,{ }^{* \star} p$ adjusted-values $<0.01$. B) Network plot for Pearson correlations among analysed traits and establishment success indicators. Correlations vary from red (+) to blue (-). Some indicators were previously transformed (see Methods). lindicators and traits are clustered according to their correlation coefficients. 
The appearing plot conditions for correlations are: 1) $p$-values $<0.05$ ) and 2) $R>0.4$. For the correlation values see A. For more detailed representations of the correlations shown, see Fig. S.1.

\section{Supplementary Files}

This is a list of supplementary files associated with this preprint. Click to download.

- Supplementarylnformation.docx 